\title{
TEST MONITORING OF THE SPEECH COMPETENCE OF STUDENTS OF MODERN HIGHER EDUCATION INSTITUTIONS
}

\author{
Valentyna Vitiuk ${ }^{1}$, Nadiia Skrypnyk ${ }^{2}$, Ivan Khomiak ${ }^{3}$ \\ ${ }^{1}$ Department of philology and methods of primary education, Lesya Ukrainka Eastern European National University, Lutsk, Ukraine \\ ${ }^{2}$ Department Communal Institution of Higher Education, Vinnytsia Humanitarian and Pedagogical College, Vinnytsia, Ukraine \\ ${ }^{3}$ Academy of the Higher School of Ukrainian Language and Literature, National University «Ostroh Academy», Ostroh, Ukraine
}

\begin{tabular}{l} 
A R T I C L E IN F O \\
\hline Article history: \\
Received date 31.03 .2020 \\
Accepted date 20.04 .2020 \\
Published date 30.04 .2020 \\
Section: \\
Professional Development \\
D O I \\
10.21303/2313-8416.2020.001281 \\
K E Y W O R D S \\
test monitoring \\
closed-ended multiple choice test tasks \\
test rules for matching rules and \\
examples \\
open-ended test tasks \\
spelling competence of students \\
duplication of letters
\end{tabular}

ABSTRACT

The object of research is the process of forming the spelling competence of future teachers of the New Ukrainian School.

Investigated problem. The spelling competence of students of higher education institutions as a component of linguistic and communication competence is presented in the article. The problem of the formation of linguistic and communicative competence, in particular spelling, is of particular relevance in connection with the introduction of the new edition of Ukrainian spelling. In the context of current requirements for the professional training of future specialists of the New Ukrainian School, the role of test monitoring as a form of diagnostics and control of spelling and punctuation literacy of higher education students is increasing, which allows to objectively evaluate the spelling of students' skills, improve the organization of educational activities and in modern universities.

The main scientific results. A brief overview of the history of testing use in the educational process is provided in scientific intelligence. The positive and negative factors of the introduction of testing in the process of studying the spelling material of modern Ukrainian literary language are determined. Guidelines for the development of spelling test tasks in modern Ukrainian have been made. The article proposes test tasks of closed and open forms for monitoring the spelling knowledge, abilities and skills of students of institutions of higher education after studying the topic «Letter doubling».

The field of practical use of research results. The results of the study can be used by teachers of higher education who are working on the problem of formation and improvement of spelling literacy of applicants for higher education institutions, as test monitoring allows promptly checking students' educational achievements, determining how thoroughly and correctly each student has mastered one or another spelling knowledge, skills.

Innovative technological product. Test tasks of closed and open forms on the theme «Letter doubling» are developed.

Scope of innovative technological product. The methodical recommendations for the development of spelling tests of modern Ukrainian language, the proposed test tasks on the subject of «Letter doubling» can be applied in the study of such subjects as «Modern Ukrainian language with a practicum», «Practice in Ukrainian spelling» for students of specialty 013 «Primary education», 014 «Secondary education», specialization «Ukrainian language and literature» of higher education institutions.

(C) The Author(s) 2020. This is an open access article under the CC BY license http://creativecommons.org/licenses/by/4.0).

\section{Introduction}

\section{1. The object of research}

The object of the research is the process of forming the spelling competence of future teachers of the New Ukrainian School. Nowadays, the question of students' vocabulary skills, their spelling literacy is of particular relevance in connection with the adoption of a new legal framework for the Ukrainian language, the new Law of Ukraine «On Ensuring the Functioning of the Ukrainian Language as State» (April 25, 2019 No. 2704-VIII) [1], and approval of the new edition of the Ukrainian Spelling (Cabinet of Ministers of Ukraine Resolution No. 437 of May 22, 2019) [2]. 


\section{2. Description of the problem}

At the present stage of higher education development, the search for advanced methods of measuring the level of educational attainment of students of higher education institutions occupies a special place. The rapid spread of new educational technologies makes it possible to predict the results of learning activities, first of all, to correlate the acquired knowledge with the ultimate goal of learning [3]. With the help of testing, it is possible to check quickly the students' educational achievements, how thoroughly and correctly the student has mastered a particular material, to determine quickly the level of successful mastering of the material and to correct the gaps in knowledge, skills and abilities.

In the context of current requirements for the professional training of future teachers of the New Ukrainian School, the role of linguistic competence of students of higher education institutions is increasing. Testing as a form of diagnosis and control of spelling literacy of students is becoming more widespread in the educational process, as it has certain advantages over other forms of control of the knowledge, facilities and skills of higher education students.

In modern methods the problem and development of test problems and their correct methodical application are still relevant and unresolved, as the qualitatively passed tests give an opportunity to assess quickly the knowledge of the of higher education students.

Theoretical foundations of the development of test tasks as a tool for measuring the educational achievement of educational recipients are shown in the works of foreign researchers: $\mathrm{Ch}$. Greene [4], N. Wainer [5], J. Miller [6], D. Fletcher [7], F. Freemen [8], Ch. Shiken [9] and others. Ch. Greene analyzed the advantages and disadvantages of tests, offered his classification and recommendations for the development of tests: the need to accurately determine the volume of test material, identify the test form experimentally, accurately determine the duration of tests, placing questions in increasing order of difficulty, avoiding regularity of correct alternation of correct replies [4, p. 11-13]. J. Miller proposed to set the duration of testing depending on the rate of completion of the main group of students, with the necessary condition for testing and at the same time he considered the teacher's tact [6, p. 168]. F. Freemen conducted a historical analysis of the development of testing in the United States and outlined the main directions of its further development: the creation of pedagogical tests aimed at measuring the level of learning, skills and competences at different stages of education, as well as the creation of tests aimed at determining the level of general mental development and special abilities for further learning [8, p. 5].

In research of L. Bilousova, O. Kolgatin, L. Kolgatina testing is presented as modern automated systems, which can be qualified as expert systems, capable of providing complex algorithms of the process of testing and analysis of test results of educational applicants, and therefore the processing of test results provides the maximum information for the subject and the teacher regarding the further correction of the educational process.

Works of scientists R. Hambleton [11], W. Sands [12], J. Spray [13], R. Swets [14], P. Wainer [15] presented the experience of testing on computers, which regulates the level of complexity tasks in the test and as a result, a more accurate measurement of individual capabilities. W. Sands, V. Kanal [12] developed a communicative model of language testing, incorporating grammatical, sociolinguistic and strategic competences [12]. According to foreign experts, computer-based testing is a real alternative to traditional form testing, which is able to reach large groups of educational recipients, provide prompt and objective control of knowledge throughout the study of all material.

The analysis of the special literature on the problem under study shows that the problem of test control, in particular the psychological and pedagogical aspects of monitoring support, has been given due attention in the works of V. Avanesov, A. Alekseyuk, Y. Babansky, V. Bespalko, S. Martynenko, O. Savchenko, P. Podkasy, etc. Thus, V. Avanesov worked on the development of science-based tests, considering the pedagogical test «a system of tasks of specific form and content, located in increasing complexity, which allows measuring qualitatively the level of training of applicants and evaluating the structure of their knowledge» [16, p. 19]. The scientist researched questions of construction of test tasks, asserting that «test tasks represent not questions and not tasks, and not riddles with which they are often confused, but statements which depending on the answers of the subjects can turn into true or false statements». V. Avanesov suggested the following system of tasks in test form: chain, thematic, textual and situational [16, p. 32]. I. Bulakh [17]; Y. Dovgopolova [18]; V. Leonsky, G. Leonsky, L. Paraschenko [19] consider the test as an effective 
means of diagnostics of the formed knowledge, skills, characterized by validity, standardization, objectivity of data at the time of its application. V. Leonsky notes that the main tasks of control are to identify the level of correctness, volume, depth and effectiveness of the acquired knowledge, obtain information about the nature of cognitive activity, the level of independence and activity of students in the educational process, to establish the effectiveness of methods, forms and methods of their learning [8, p. 92].

Z. Bakum, O. Goroshkina, S. Karaman, O. Karaman, O. Kopus; N. Golub [21] and others have written in the works about the problems of control and verification of students' educational achievements, taking into account the specifics of the educational process in institutions of higher education. However, observations of the educational process, surveys of students and teachers have convinced them that most often, in order to control the formation of students' linguistic competence; teachers use non-standard (self-contained) tests of closed and open forms.

\section{3. The intended way to solve the problem}

In Ukraine, for a long time, tests were made as an instrument of individual measurement, but the mass of testing is due to the need to move from individual tests to group tests, whose main task is to measure the level of intellectual development, the success of students in certain disciplines over a certain period of study. As the test system is a relatively new type of ongoing and thematic assessment of students' knowledge, as well as self-organization and self-control, it needs further resolution. This is not only related to the introduction of the test control to the educational process and increasing requirements of the test, but also to standardizing procedures for evaluating the educational achievement of educational recipients. Important issues related to the lack of sound testing methodology for studying sections of linguistics of the discipline «Modern Ukrainian language with a practicum» in higher education remain unexplored. In view of this, let's have determined the purpose of scientific and methodological intelligence.

The purpose of the article is to investigate the effectiveness of test monitoring, to develop test misspellings of modern Ukrainian, and to test their effectiveness.

\section{Materials and methods}

Analysis of the scientific literature has shown that the problem of the use of testing in the educational process has been studied for over a century, as well-known educators of the past also looked for effective ways of diagnosing the quality of the acquired knowledge. In the early twentieth century, 1864, in England, J. Fisher created special books «Scale books», which asked questions and options for choice when checking students' level of knowledge. Books contained questions on spelling, arithmetic, reading, grammar, navigation [22]. These works can be considered as the first models of school tests of success, although the theoretical foundations of testing were developed much later.

In 1884, the first collection of tests was published in the United States, containing mathematics, history, grammar, navigation and answers. The results were evaluated on a five-point scale. This book also provided sample texts of the works and indicated methods for quantifying them. It was the first time in history that the simplest statistical calculations were used in pedagogical work. This form of control quickly spread to the United States, although it had not only supporters but also opponents who believed that no one better than a teacher could evaluate student's ability [23]. In 1894, J. M. Rice began testing at school, creating three different spell-check tests. J. Rice evaluated the results on the five-point scale he had created. However, despite the novelty of J. Rice's research, his works were not appreciated by contemporaries [24, 25].

The founder of the use of tests in US pedagogy, however, is considered by E. Thorndike, who has concluded the methodological aspects of test development in pedagogy. In 1903, W. Thorndike published a book called Educational Psychology, which described the types of tests that could be used to evaluate students' educational achievement. During the years 19101911, the quality of education in New York City's free schools was tested. For this purpose, tests were used to measure student achievement as a means of checking the effectiveness of the school system [23]. 
In 1913, B. Buckingham developed a spelling scale, which was later borrowed by many specialists to perform testing in various subjects: L. P. Aires used it for his «Spelling Scale», S. Woody - for tests to check mathematical operations, Kh. Khotsom - to test the measurement of knowledge in algebra, W. Khanmon and Kh. Brown - to establish students' level of mastering the Latin, M. Trab - to determine students' linguistic knowledge and skills, M. J. Van-Vagenen to examine the performance of history tests [24].

In 1914, the Union of American School Boards approved testing as an objective method of measuring and evaluating knowledge, and since then the United States has begun to apply testing actively [17].

Famous American researcher F. N. Freeman conducted a historical analysis of the development of testing in the United States and outlined the main directions of its further development: the creation of pedagogical tests, the purpose of which is to measure the level of assimilation of knowledge, skills at different stages of learning, as well as the creation of tests aimed at is to determine the level of general mental development and special abilities for further learning [8, p. 5].

C. Greene in the monograph «Tests of a new type» analyzed the advantages and disadvantages of tests, proposed its classification, and developed the following recommendations for the development of tests: the need to accurately determine the volume of material for testing, identify the test form experimentally, accurately determine the duration of tests, placement of questions in the order of increasing complexity, avoiding regularity of alternation of right and wrong answers [4, p. 11-13].

In the 20-30 are of the twentieth century in Ukraine, A. Mandirko and M. Sirkin investigated theoretical aspects of testing, criteria for the correctness of test trials. During the 30-50s, tests were considered as «bourgeois tool» and were banned in education. At the same time, M. Basov noted that «a long and sharp criticism of the test methodology ... in the end will lead not to overthrow, not to the abolition of this methodology, but on the contrary, to its strengthening and approval to the extent to which it obviously has right to use and existence» [23]. During this period, the elements of testing, without mentioning the appropriate term, were used to test students' academic achievement in secondary schools, as evidenced by test case samples in exercise books, control tasks.

In March 1969, the Central Council of the Union of Psychologists of the USSR was asked about the implementation of an individual approach to training and decided on the official «permission» to use the tests. In the 70's of the XX century collections of exercises and tasks with signs of testing were widely distributed. Their authors were V. Bespalko [23], S. Arkhangelsky [26], L. Itelson [27], N. Talizin [28] and others. However, until the mid-1970s, discussions on the use of testing continued, which were discontinued in the early $1980 \mathrm{~s}$.

Following the signing of the Bologna Declaration (1999) by Ukraine, one of the important directions of reforming the national education system was the development and implementation of qualitatively new approaches to the assessment of educational achievements of pupils and students. Testing has been recognized as one of the approaches, so tests are used actively in conducting state-independent assessments of educational attainment of graduates of general education institutions, at entrance, final examinations of higher education institutions, although their quality has not meet the requirements of international standards yet.

In the context of this study, let's recommend the use of testing to diagnose and control of spelling literacy of pedagogical college students. It is worth noting that the use of testing is not limited to the form of diagnosis and control, testing can also be used as a form of assimilation of certain spelling material. In our opinion, the test should be understood as the task of the standard form, arranged in order of increasing complexity, and the performance of which should reveal a certain level of knowledge, students' facilities and skills; testing is a process in which all students are assigned the same tasks, work in the same conditions, and the results of the answers are evaluated against the same criteria.

The analysis of linguistic and didactic literature and our own scientific and pedagogical experience allow to identify both positive and negative factors of the introduction of testing in the process of studying the spelling material of modern Ukrainian literary language. 
The main advantages of using the test control of students' knowledge, skills and abilities are the following:

- ability to embrace all students of the group at the same time to carry out both current and final control;

- saving of study time for carrying out diagnostics and control of spelling literacy of students;

- objectivity of test control, which excludes subjective evaluative teacher's judgments and conclusions, teacher's emotional influence on the student;

- ability to use computer equipment, to combine modern pedagogical teaching technologies;

- presence of a specific one-to-one answer, standard evaluation based on defined criteria;

- possibility of individualization and differentiation of control with determination of a certain level of students' education, formed students' spelling competence.

However, testing can't be considered as the only unified form of students' spelling diagnosis and control, as tests mainly examine the knowledge of spelling rules and partially check the spelling and punctuation skills, but can't assess the creative level of student's spelling competencies, because the availability of variants creates the ability to answer approach to solving the spelling problem. In addition, the possibility of guessing the correct answer for certain forms of test tasks is not excluded.

Before testing students, let's suggest that the following methodological guidelines for developing spelling tests in modern Ukrainian are considered:

1. Determining the purpose of testing. For example, diagnostics of individual spelling topics, a certain spelling section, independent study of spelling material, final control of spelling knowledge, facilities and students' skills.

2. Selection of the content of spelling material, taking into account the changes of the new edition of «Ukrainian spelling» (resolution of the Cabinet of Ministers of Ukraine No. 437 of May 22, 2019) [2].

3. Designing a test matrix that involves the inclusion of all spelling material, or testing on separate topics, but in this case, it is necessary that the entire topic is covered by the tasks of the test. For example, in the test collection «Spelling» [29], let's have structured spelling material into the following sections: «Spelling of parts of the word base», «Spelling of endings of cancellable words» and «Spelling of words of foreign origin». Within each section, spelling topics were isolated and test tasks assigned to them.

4. Formation of the structure of the bank of test tasks. Let's propose to use closed and open form test tasks. Multiple-choice closed-ended test tasks examine the ability to spell correctly the letter and include four possible answers, of which only one is correct. Closed-form test tasks for matching make it possible to test not only the knowledge of spelling rules, but also the ability to navigate in spelling material, to establish the correspondence between rules and specific words-examples. When evaluating such tasks, the number of points is equal to the number of correctly answered answers within a single task. In open-ended tasks, let's suggest writing down exception words or compound words in writing (at least 10); write out words with control spellings from the text, classify them according to the rules; introduce new words with control spellings into the mini-context.

5. Testing.

6. Evaluation and analysis of test results.

Nowadays, it is possible to do computer testing using online resources: Moodle, Google Forms, Kahoot, Class Marker, Easy Test Maker, PLICKERS and more.

\section{Results}

In today's higher education institutions, learners deepen their knowledge of Ukrainian literary language while studying such disciplines as «Contemporary Ukrainian language with a practicum», «Practicum on Ukrainian spelling», «Ukrainian language (by professional direction)», differentiate the volume and content of linguistic knowledge, facilities and skills, improve the free operation of language resources, especially Ukrainian literary language.

It is possible to increase students' level of spelling competence by carrying out continuous test monitoring after studying each topic. For example, after learning the theme of «Letter doubling», let's suggest students to complete the following test tasks: 


\section{Multiple choice closed form test tasks}

1. In all words of which line there is a doubling of letters.

a) (в/вв)ічливий, письме $(н / \mathrm{Hн})$ ик, нескінче $(\mu / \mathrm{Hн})$ ий;

b) довгожда $(н / \mathrm{Hн})$ ий, $n a(c / c c) я$, зробле $(н / \mathrm{Hн})$ ий;

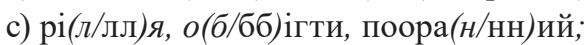

d) числе $(н / \mathrm{Hн})$ ість, коло $(c / \mathrm{cc}) я$, олов'я $($ н/нн)ий.

2. In all words of which line there is an extension of letters.

a) знаря (д/дд)я, зна $(н / \mathrm{Hн}) я$, ку $(m / \mathrm{Tт}) я$;

b) (л/лл)ються, ні(ч/ч)ю, прияз $(н / \mathrm{нH}) ю$;

c) навма $(\mathrm{H} / \mathrm{Hн}) я, м и(m / \mathrm{Tт}) ю, ~ с у(\partial / д д) я$;

d) жи(т/тт)єрадісний, жи $(m /$ тт)ейський, щฺе(н/нн)я.

3. Which line misspelled the spelling of the word.

a) буквений, білопінний, тонна, сюрреалізм;

b) виховання, блаженний, намальований, сума;

c) Галичина, осінній, мерзенний, скажений;

d) нетлінний, беладонна, статей, суиявітmя.

4. Read the text fragment. Determine which digit does NOT duplicate letters and lengthen consonants.

Наш народ має багату культуру, величез(1)ий скарб якої складається з ці(2)остей, надбаних багатьма поколі(3)ями. 3 прадавніх часів до нас ідуть життєва мудрість та настанови щуодо способужиття. Вони закладені в украӥнських звичаях, обрядах, фольклорі, адже в них - світовідчу(4)я та світосприйма(5)я нашого народу. У них пояснюються та обтрунтовуються взаємини між людьми, иі(б)ість духовної культури окремої людини і народу взагалі. Дуже тісно народна творчість пов язана зі звичаями, що являють собою закони, якими українці керувались щоде(7)о (3 журналу).
a) 5
c) 1
b) 3
d) 6

5. Read the text fragment. Determine which digit does NOT duplicate letters and lengthen consonants.

Від сивої давни(1)и і до сьогодні чільне місце в українському побуті займає рушник. 3 ним народжуються, одружуються і йдуть із жи(2)я. 3 хлібом-сі(3)ю на рушнику зустрічають дорогих гостей. Без нього не обходиться жодна урочиста подія в роди(4) ому чи громадському жи(5)і. Незабут(6)ій О. Гончар якось сказав, що Україна має стільки рушників, що ними можна оперезати всю земну кулю. Наш рушник $є$ і оберегом, і молитвою, і засобом спілкува(7)я з предками (3 журналу).
a) $1,5,6$
c) $2,4,7$
b) $2,3,4$
d) $1,3,5$

6. Read the text fragment. Determine which sentence is misspelled.

(1) Багаті й родючі землі Поділля та розвинені шляхи сполучення здавна сприяли в изьому краї розвиткові усіх видів народного мистецтва, зокрема, настінного малювання, художнього ткацтва (килими, верети, налавники), мальованих меблів та посуду, настінних прикрас-витинанок. Тому на Поділлі, особливо Західному, рушник, як хатня прикраса, не набув значного поширення. (2) Знає Поділля як ткані, так і вишивані рушники. (3) На Східному Поділлі ткані рушники мають розвинену орнаментику, на Західному вони нагадують невеликі за розмірами рушники Полісся i Карпат. (4) Побутували також і багато оздобленні, «святошні» рушники - багатоколірні, 3 суцільними та орнаментальними смугами.
a) 1
c) 3
b) 2
d) 4 
7. Read the text fragment. Determine which sentences are misspelled.

(1) Візерунки на рушниках мають особливе значення - то ніби обереги від злої сили, від лиха. (2) Раніше свяченним рушником витирали дитину, щоб «збити» високу температуру. (3) Рушником зв’язували молодих, щоб завжди були разом. (4) 3 ним виряджали в далеку дорогу батька, сина, чоловіка й коханого. (5) Рушником зустрічали родичів і гостей, ним прикривали хліб на столі. (6) 3 рушником проводжали людину в останню путь. (7) I в наші часи український народ не розлучається з рушником традиційнним елементом оселі і святковим символом. (8) Вишитий рушник прийшов 3 тієї ж сивої давнини, що й народна пісня. (9) І тепер, дивлячись у ту саму давнину, ми бачимо не полотно з яскравими нитками, а долю українського народу, вишиту на ньому, оспівану в народних піснях.
a) 1,2
c) 4,9
b) 2,7
d) 5,6

Test tasks for matching rules and examples

8. Match the rules with the examples below

\begin{tabular}{|c|c|}
\hline $\begin{array}{l}\text { 1. Подвоюються букви на межі значущих частин слова, якще } \\
\text { одна з них кінчасться, а друга починається на ту саму букву }\end{array}$ & $\begin{array}{l}\text { молоддю, сіллю, розкішшю, } \\
\text { подорожжю, миттю }\end{array}$ \\
\hline 2. Подвоюються внаслідок різних збігів букви & Вінниччина, Німеччина, козаччина \\
\hline $\begin{array}{l}\text { 3. Подвоюсться ч в іменниках, утворених від прикметників } \\
\text { на -цуьк(ий) }\end{array}$ & бовваніти, ссати, лляний, Ганна, овва \\
\hline $\begin{array}{l}\text { 4. Перед ю в орудному відмінку іменників жіночого роду однини } \\
\text { третьої відміни, якщчо в називному відмінку їхня основа має } \\
\text { один м'який або шиплячий приголосний }\end{array}$ & $\begin{array}{c}\text { віддати, беззвучний, законний, денний, } \\
\text { годинник }\end{array}$ \\
\hline
\end{tabular}

Open-form test tasks

9. Write down words that are difficult to spell (at least 10 words).

10. Explain why in groups of words здійсне́нний and здійснений, нездола́нний and нездо́ланий, незліче́нний and незлічений duplication occurs in some cases and not in other words.

The analysis of the results of the test tasks of the control and experimental groups of students of the first year, that's at the beginning of the experimental study, is shown in Fig. 1, the results of continuous implementation of test monitoring during the study of the course «Practice in Ukrainian Spelling»at the end of the second semester of the second year are shown in Fig. 2.

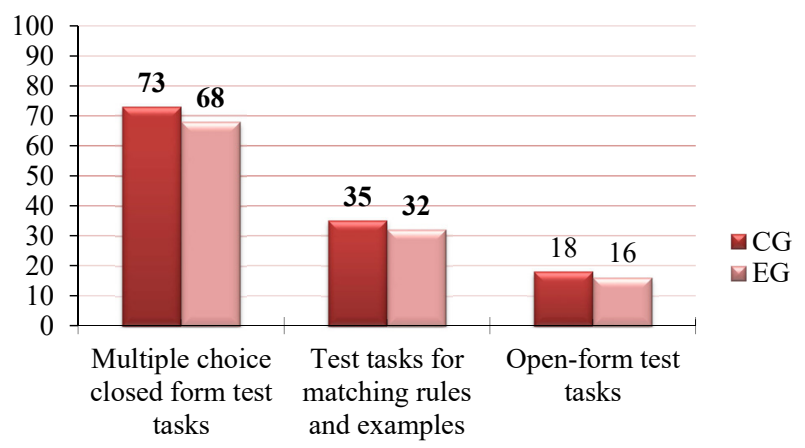

Fig. 1. Comparative diagram of the results of the performance of test tasks by students at the beginning of the first semester and the first year 


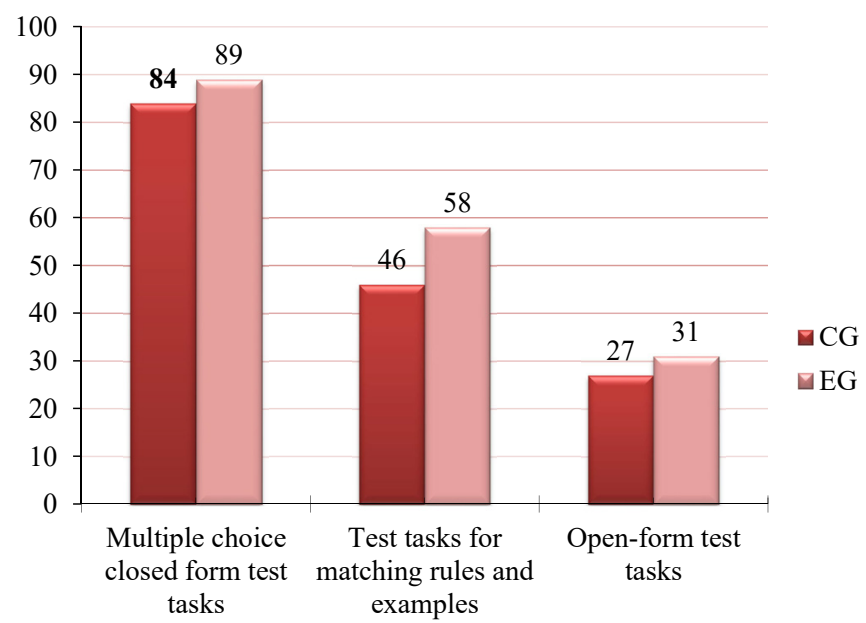

Fig. 2. Comparative diagram of the results of the test assignments by students at the end of the second semester of the second year

\section{Discussion}

Based on the analysis of the results of the continuous performance of the test tasks in the experimental groups, it is possible to say that students of the experimental groups have higher scores, respectively, which is illustrated in the comparative diagrams. The results also indicate that the most difficult task for students is to complete open-ended test and they do best with multiple-choice closed-form tasks, in particular for choosing one correct answer from the four offered. In addition, in the experimental groups, the stronger students performed the test tasks quickly, reasonably, but the weaker, though mistakes were made while completing tasks, became interested in the subjects «Modern Ukrainian language with practicum» and «Practice in Ukrainian spelling». Their desire to know the mother tongue better, to be competent increased. This led to the expediency of our scientific and methodological exploration, since the problem of the use of test monitoring in the process of studying the spelling and punctuation of the Ukrainian language was not the subject of special study of modern linguodidacts, despite the fact that the use of tests as an effective form of testing the level of learning is not new in modern linguistics. Thus, the works of O. Avramenko [30], G. Bondarenko [31], L. Pletnev [32] and others are devoted to determining the features of compiling and using tests in the Ukrainian language classes in the institutions of general secondary and higher education. O. Avramenko, as one of the developers of the program of external independent assessment, has completed the tests of the Ukrainian language and literature for high school students [30]. V. Novosolova, L. Pletnova [32] completed test tasks to prepare students for external independent assessment. Let's fully agree with G. Bondarenko, who believes that the use of the test methodology allows: «to stimulate and support the students' interest in studying the proposed material; to test not only the final product of the educational activity, but also to control the process of formation of knowledge, facilities and skills, thus realizing two control functions - training and control; to check at the same time all students of the group, because during the test they are all in equal conditions, work with the same volume and complexity of the material, which eliminates the possibility of influencing the assessment of such factor as luck/bad luck; to perform tests at any class, because their implementation takes little time» [31, p. 7].

Prospects are seen in the development and scientific substantiation of ways to introduce test control of the educational achievements of future teachers of the New Ukrainian school by means of information and communication technologies, the development of a system of test tasks, as well as methodological recommendations in the format of classroom and in distance learning the discipline «Modern Ukrainian language with a practicum» for students of higher education institutions.

\section{Conclusions}

1. The analysis of test monitoring as a form of diagnostics and control of spelling literacy of students of higher education institutions is carried out. 
2. A brief overview of the history of application of testing in the educational process is carried out, the positive and negative factors of the introduction of testing in the process of studying the spelling material of modern Ukrainian literary language are identified.

3. The methodological recommendations on the development of spelling tests in modern Ukrainian were concluded, the test tasks were developed and their effectiveness was experimentally tested in the course of studying the discipline «Practice in Ukrainian spelling».

\section{References}

[1] Pro zabezpechennia funktsionuvannia ukrainskoi movy yak derzhavnoi (2019). Zakon Ukrainy No. 2704-VIII. 25.04.2019. Available at: https://zakon.rada.gov.ua/laws/show/2704-19 Last accessed: 05.07.2019

[2] Pytannia ukrainskoho pravopysu (2019). Postanova Kabinetu Ministriv Ukrainy No. 437. 22.05.2019. Available at: https:// законодавство.com/ministriv-kabineta-postanovi/postanova-vid-travnya-2019-437-pitannya-2019-71792.html

[3] Dyiak, O. V., Prudka, V. M. (2015). Ukrainska mova: kompleksne vydannia dlia pidhotovky do ZNO. Kyiv: Litera LTD, 512.

[4] Greene, Ch. E. (1926). New Type Tests: Number Three. Denver, 35.

[5] Wainer, H. et. al. (1990). Computerized Adaptive Testing. A primer. Lawrence Erlbaum Associated, Publishers, 300.

[6] Miller, J. F. (1926). Objective Tests in High School Subjects. Norman, 168.

[7] Fletcher, D. (2009). Standardized Testing. Friday. Available at: http://content.time.com/time/nation/article/0,8599,1947019,00.html

[8] Freemen, F. N. (1926). Mental Tests. Their History, Principles and Applications. Boston, New York, Chicago, Dallas, San Francisco, 491.

[9] Shiken, Ch. (2006). JALT Testing and Evaluation. SIG Newsletter, 10, 8-16.

[10] Bilousova, L., Kolgatin, O., Kolgatina, L. (2013). Pedagogical Diagnostics with Use of Computer Technologies. Proceedings of the 9th International Conferenceon ICT in Education, Research and Industrial Applications: Integration, Harmonization and Knowledge Transfer. Kherson, 209-220.

[11] Hambleton, R. K. (1997). Handbook of Modem Item Response Theory. Editors Win Ivan der Linden. New York: SpringerVerlag, 510.

[12] Sands, W. A., Walters, B. K., Mcвride, I. R. (1997). Computerized AdaptiveTesting: From Inguiry to Operation. New York. doi: http://doi.org/10.1037/10244-000

[13] Spray, J. A., Reckase, M. D. (1994). The Selection of test items for decision making with a computer adaptive test. I Paper presented at the national meeting of the National Council on Measurement in Education. New Orleans.

[14] Swets, R., Zeitlinger, K. (1989). An applied study on computerized adaptive testing. Amsterdam.

[15] Weiner, P., Dorans, N., Flaugher, R., Mislevy, R., Green, B., Steinberg, I., Thissen, D. (1990). Computerized Adaptive Testing. New York, 300.

[16] Avanesov, V. S. (1994). Nauchnye osnovy testovogo kontrolya znanii. Moscow: Issledovatel'skii centr, 135.

[17] Bulakh, I. Ye. (1995). Teoriia i metodyka kompiuternoho testuvannia uspishnosti navchannia (na materialakh medychnykh navchalnykh zakladiv). Kyiv: Kyivskyi un-t im. T. Shevchenka, 430.

[18] Dovhopolova, Ya. V. (2011). Vprovadzhennia testovoi metodyky v protses navchannia u vyshchykh navchalnykh zakladakh. Available at: http://ekhnuir.univer.kharkov.ua/bitstream/123456789/6516/2/11dyvvnz.pdf Last accessed: 10.04.2020

[19] Parashchenko, L. I., Leonskyi, V. D., Leonska, H. I. (2006). Testovi tekhnolohii u navchalnomu zakladi. Kyiv: TOV «Maisternia knyhy», 217.

[20] Horoshkina, O., Karaman, S., Bakum, Z., Karaman, O., Kopus, O.; Horoshkina, O., Karaman, S. (Eds.) (2015). Praktykum z metodyky navchannia movoznavchykh dystsyplin u vyshchii shkoli. Kyiv, 250.

[21] Holub, N. B. (2008). Rytoryka u vyshchii shkoli. Cherkasy: Brama-Ukraina, 400.

[22] Tsaturova Y. A., Baluian S. R. (2004) Testyrovanyia ustnoi kommunykatsyy. Moscow: Visshaia shkola,127.

[23] Avanesov, V. S. (1982). Testy v sociologicheskom issledovanii. Moscow: Nauka, 200.

[24] Burlachuk, L. F. (2006). Psihodiagnostika. Saint Petersburg: Piter, 351.

[25] Kadnevskii, V. M. (2004). Testovaya kul'tura kak fenomen civilizacii. Obrazovanie: issledovano v mire, 10.

[26] Arhangel'skii, S. I. (1980). Uchebnyi process v vysshei shkole, ego zakonomernye osnovy i metody. Moscow: Vysshaya shkola, 368.

[27] Itel'son, L. B. (1972). Lekcii po sovremennym problemam psihologii obucheniya. Vladimir, 191.

[28] Talyzina, N. (1998). Pedagogicheskaya psihologiya. Moscow: Akademiya, 288.

[29] Vitiuk, V. (2019). Orfohrafiia. Zbirnyk testovykh zavdan. Lutsk: AKVA PRINT, 175.

[30] Avramenko, O. (2020). Ukrainska mova ta literatura. Zbirnyk zavdan u testovii formi. Kyiv: Hramota, 144.

[31] Novosolova, V. I., Pletnova, L. V. (2007). Testovi zavdannia z ukrainskoi movy (dlia pidhotovky do zovnishnoho nezalezhnoho otsiniuvannia). Ukrainska mova i literatura v shkoli, 6, 47-57. 